\title{
Contrapuntal Significations in Wole Soyinka's Death and the King's Horseman
}

\section{*Olagoke Olorunleke IFATIMEHIN}

\begin{abstract}
Wole Soyinkaô Death and the King's Horseman has been widely acclaimed as a great example of African tragedy. It is, in fact, the dramatic aggregation of Soyinkaôs treatise in Myth, Literature and the African World. Hence, the play is most often óreadôin the lights of its ádifferenceô from western notions of the tragic, the place of ritual in African drama and the interface of myth and history in creating drama, among others. As a result of these, and influenced largely by the author $\hat{Q}$ note on the play, Death and the King's Horseman is rarely considered as a play on the álash of culturesô which is usually viewed as a óreductionistô orientation or reading. This article, however, engages the text from the purview of cultural clash in order to apprehend the very catalyst that sparks the tragic concerns in it. By applying deconstructionist reading upon the text, the paper plies on the horizon of contrapuntality and alterity to reveal significations which hint at the difference in cultural worldviews as the essence of the tragedy that is Death and the King 's Horseman. It also suggests that such a reading enriches, rather than reduces, the textuality and significations of the play beyond pseudo-scientific taxonomies.
\end{abstract}

Keywords: Deconstruction, Wole Soyinka, Contrapuntality, Alterity, Significations

\section{Introduction}

Deconstruction is a method of reading which dismantles the notion of structure or centre of meaning in a text by implying the existence of meanings. Largely attributed to Derrida (1984), deconstructionprovides a system of reading which goes against

* Olagoke Olorunleke IFATIMEHIN of the Department of Theatre and Performing Arts Bayero University, Kano Email: ioolagoke.tfs@buk.edu.ngmultiple 
established meanings and authorial intentions by óseeking outô connotations, usually contradictory, within a text which goes ágainst the grainôof inferential logics. Cuddon (1999) notes that:

A reader tends to construct a sub-text for herself or himself, imagining or interpreting what is not said or not done (and how it is not said or done), what may be implied, suggested or hinted, what is ambiguous, marginal, ambivalent, evasive, emphasized or not emphasized and so on. In doing all this, the reader exercises insight into the ánconsciousôelements in the work itself and thus elicits additional meanings.

Deconstruction opens up texts rather than inhibit them in closures of meaning. In other words, it thrives on the interpretation of texts as essentially sign systems hinting at a plethora of potential meanings rather than conclusive clusters of unilateral definitions. This is why semiotics is a quintessential parameter in deconstructive reading. According to Balme (2008), semiotics ñooks at phenomena (including theatrical performances) in terms of the signs and codes used and the way they generate meaningò. In other words, semiotics is the study of signs and how they articulate meaning. Deconstruction, in this light, is the application of semiotics in order to demonstrate the existence of deeper levels of meaning beyond superficial expressions in texts. Derrida (1984) states that:

To write is to produce a mark that will constitute a kind of machine that is in turn productive, that my (an authorôs) future disappearance in principle will not prevent from functioning and from yielding itself to reading and rewritingé . The situation of the scribe and the subscriber, as concerns the written, is fundamentally the same as that of the reader.

This denotes that every text is a sign, and each sign could mean a different thing to different readers (spectators). Semiotics developed out of linguistics, largely from the notions of Ferdinand de Saussure and Charles Sanders Pierce that the structure of 
language goes a long way in determining the structure of sign systems and their meaning(s). Before this notion, ñanguage had been viewed as a transparent medium through which reality could be set down accurately and shaped into an aesthetic formò (Dobie, 2012). However, for semiotics:

Languages make meaning only
differentially; that is, within a given
language; words only derive meaning by
reference or contrast to other words. The
particular system makes meanings possible
through rules, conventions, and distinctions.
Saussure theorized an important difference
between la langue (the overall language
system) and la parole (the particular speech
act or utterance). La parole only means
something because of the enabling system of
la langue. Since not only languages but also
human behaviours and customs are signs
that operate within the organizing patterns
of social systems, Saussure called for a
ósience of semiologyô(Reinelt and Roach,
1999).

Although this position accentuates that meaning can only be derived within the superstructure that creates it, it also hints at the arbitrariness of meaning in language. Of more significance here is the explanation of language system as an engagement with signs. Dramatic and performance texts are a combination of encoded signs which the reader/spectator is expected to decode, untie or unfix. Aston and Savona (1999) relate the study of textual material as a ñconsideration of its unfixing in the plurality of signifying processes generated through the activity of reading/spectating.ò

Saussure observed that signs are usually bifurcated, embodying the signifier and the signified. The signifier is what is seen or heard while the signified is the concept or meaning the signifier generates (Dobie, 2012; Reinelt and Roach, 1999). Unlike 
Saussureôs position that sign would refer to a definite term or concept, deconstruction ñwent a step further, stating that any given signifier may point to several different signifiedsé . In short, a signifier has no single signified, or mental concept, as the structuralists assume but instead leads to a chain of other signifiersò (Dobie, 2012). Derrida had mentioned that there is no óranscendental signifiedôin any text.

The role and function of deconstructive analysis is not to locate the meaning of a text, as there is no singular meaning to a text but a plethora of possible meanings (interpretations) which are, in themselves, only provisional. Viewing the reading of a text in this manner ultimately suggests that meaning is fluid and contextual. For Soyinka and other scholars to limits Death and the King's Horseman to a depiction of mythopoesy and warns against a study that seeks to understand the nature and implications of clash of cultures as a theme, is therefore heinous on the business of research and the search for more meaning.

Death and the King's Horseman: Pretext, Text and Context

Soyinka revisits a historical event, which threatened the balance of the Yoruba cosmic world and the all-important task embarked upon by Ogun in constructing a bridge over the gulf that once separated humanity and the gods, to create a dramatic piece which arguably is his most important play till date. Obafemi (1996) considers Death and the King's Horseman as ñthe most potent dramatic statement Soyinka has made on transition $\ddot{i}$ the rite of passage.ò The intermingling of the mythic and historic is something after Soyinkaôs own heart as envisaged in his complex rendering and reinterpretation of Ogunôs mythic/historical role for a tragic/dramatic construct (Katrak, 1986).

The event is premised on the Yoruba custom which stipulates that following the death of the Alaafin, the chief of his stables is expected to carry out a ritual suicide in order to accompany him to the ancestral world where the inhabitants of that realm await to welcome the Alaafin into their fold. This way, the cycle of Yoruba life is not distorted. In 1946 the chief of the kingôs stables failed to play his role with the passing of the king, and by implication puts the Yoruba race at the brink of extinction, so to 
speak. Adeniran (1994) reports the historical event thus:

History confirms that the real event occurred during the reign of Ladigbolu I, after being on the throne for some 33 years. His horseman, Elesin-Oba (Jinadu) had all along been given some preferential treatment because of the belief that such favours were necessary as a pay-off for the personal sacrifice to be made by the horseman who would be expected to follow the king on his death through suicide. On the death of King Ladigbolu the horse-man made some visits here and there, dressed in white and began dancing through the streets towards the house of Bashorun Ladokun. All those who saw the event knew that he was preparing to commit suicide. Rather than be allowed to complete the process of dancing to the Bashorunôs house and eventually poisoning himself, the British Colonial Officer at Oyo ordered his apprehension and he was detained. As soon as the townôs people got to know about the arrest, the horsemanô youngest son (Murana) killed himself because he could not stand the stigma of being the son of a coward, a betrayer of tradition and botcher. This is the story that sourced Death and the King's Horseman.

This historical incident is also reported in Gibbs (1986). The event had óretextedô a play by Duro Ladipo entitled $O b a$ Waja (The King is Dead). Ladipoôs play, cited in Beier (1964), attempted to chronicle a piece of history as he notified that his play is ñbased on a true incident that happened in Oyo in 1946ò. The play, written in five acts, narrates the story of Olori Elesin who is expected to commit suicide following the death of the king. While in the market, on his way to commit suicide, Olori Elesin is 
arrested by the colonial District Officer, John, who but for the prompting of his wife, Jane, would have allowed tradition to take its course, stopped Elesin from committing suicide. In far away Ghana, Olori Elesinôs son, Dawudu is having a nice time in a đ́Highlife Barôwhen he reads in a newspaper that the king of Oyo is dead. He immediately sets to return to Nigeria to bury his father. When asked if the king who died is his father, he responds ñNo! But my father too, must die today. $\mathrm{He}$ is the commander of the kingôs horse, who must follow the king to his graveò (Beier, 1964). Dawudu returns home and meets his father, who happily blames the óvhitemanôfor this condition; the father should not be among the living at that instant. He is so shaken that he blurts, ñWhy are you alive, is the Alafin not dead?ò (85). Dawudu is so ashamed that he stabs himself and dies. Elesin finally realises the shame that has come upon him and he also kills himself.

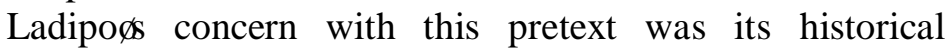
relevance. His text does not dwell on the mytho-ritualistic implications of the incident. If anything, the play retains the context of the historical event just as any one witnessing it would have recounted. But this is not so with Soyinka. Soyinka apprehends the pretext, not only from its historical perspective, but also, perhaps more importantly, from its mythopoeic textuality. Aristotle (1971), one of the earliest to theorise on drama, had favoured myth over the actuality of history as material for dramatic composition. But Soyinka does not ignore the fertility of history in nurturing myth and ritual. In fact, while situating his text within the trajectory of its historical context, Soyinka also textualises the mythic and religious innuendoes of his pretext, of history. Unlike Ladipo who employed the new historicist view of history as a ćotextô history as of equal value as the creative text it births (Barry, 2002), Soyinka regards history only as a context for other texts to spring from. This, therefore, provides a basis for his synthesis of history with myth and ritual. While Ladipo was adapting á true historical incidentô Soyinka (2012) says of his version:

The play is based on events which took place in Oyo, ancient Yoruba city of Nigeria, in 1946... The confrontation in the play is largely metaphysical, contained in 
the human vehicle which is Elesin and the universe of the Yoruba mind $\ddot{i}$ the world of the living, the dead and the unborn, and the numinous passage which links all: transition. Death and the King's Horseman can be fully realised only through an evocation of music from the abyss of transition.

He transposes the readily visible history into the very nerve of Yoruba belief system. ñFor the Yoruba, the balance of human life, the very sense of human existence, consists in the dynamic correlation of individual responsibility and the pressure of external events and forcesò (Gibbs, 1980). It is on this account that Soyinka tells the story of Elesin Oba who, with the passing of the Alafin, is expected to bridge the abyss of transition by committing suicide to accompany the spirit of the dead king thus ensuring the áontinuation of the speciesô The consequence of his inability to commit suicide portends grave danger to the society, both seen and unseen. Elesin is arrested in the market square on the order of the District Officer, Simon Pilkings, to avoid the óarbarismôof ritual suicide. The arrest is made possible because Elesin lingers to frolic with the market women and takes a new bride. His son, Olunde who is on scholarship in England returns to bury his father but meets him in chains and behind bars. His father being alive is an ominous sacrilege. He commits suicide to cover his and his familyôs shame. His father learning of this also commits suicide, except that the suicide is both late and out of context. Society is placed on a precarious precipice with hope clinging on the slippery circumstance of the unborn.

Although spiralling from a historical event, Soyinka has transformed the story to suit his mythopoeic interests. He historicises the 1946 event into a dramatic inchoate mass of ritual and myth. ñSoyinkaôs ómythopoeicôattitude to history, his constant penchant for transforming experience into metaphysical, transhistorical, mythic dimensionsò (Jeyifo 1985) provides for him the nexus for his dramaturgy. Obafemi (1996) has noted that: two principal elements in Yoruba metaphysics form the background to Soyinkaôs social vision. These elements are the belief in the 
continuity of existence through a link between the past, the present and the future, and the mutual struggle of mankind and the divinities to understand and thus remove the barrier between each other. George (1999) also aptly captures the essence of ritual to Soyinka, and its import to understanding his work, thus:

Returning to his native Yoruba cosmology and the rituals that derive from it, Soyinka elicits from ritual a drama of archetypes, developing in the process a vision of history, society, and tragic drama. A range of critical work has shown this vision to be based on a socio-cultural passion, even as the playwrightôs oeuvre constitutes an attempt to work through the passion by means of art. This understanding of Soyinka gives a sociological accent to his mythopoeic vision and aesthetic; that is, his refashioning of the Yoruba worldview emerges as, on the one hand, a theory of historical being and the often brutal adventure of the social and, on the other, of art as witness to both.

It is in the context of this background that Soyinka considerably involves in ñdramaturgical departures from his historical materialò (Jeyifo 1985) to project, not only the threnodic substance of the subject of his drama but, the visceral essence of myth and ritual (culture) to drama and tragedy. History allows the playwright to operate within its context, but should not confine him. The dramatist is not a historian in terms of chronicling past events in accurate systemic narratives. He only employs history to fashion his drama because, as Yerima (2009) puts it: history allows drama to keep its eye on life through its ability to use history as a didactical material in which the audience learn from the mistakes of history. And secondly, history allows humanity to continue to learn from life as an idea of the pedagogics.... the greatest quality of history is its ability to portray and capture the true nature of human life from one culture to another, and from one generation to another. 
Within this historical pretext is colonial presence among natives who are at peace with their value systems and beliefs. But colonialism, which fundamentally represents ácivilizationô in the play, does not share in the óbarbaricô enthusiasm of the natives. This very notion sparks animosities and disgusts between the two camps and sets the tragedy in motion. It is, therefore, essential to study the effects and implications of the colonial presence and interference with the native normalcy of events in the text for the apprehension of meaning beyond historical and mythopoeic concerns. Idegu (2007) had contested Soyinkaôs contextual aggregation of an óAfrican worldviewôin Myth, Literature and the African World, but this article promises to showcase counterpoints to already established canonical interpretations of Death and the King's Horseman.

\section{Contrapuntality in Death and the King's Horseman}

The term, contrapuntal, was coined by Edward Said (1993) to describe how texts of English literature should be read in order to reveal their deep implication in imperialism and colonialism while providing a counterpoint, or counterpoints, to the meaning of the text hitherto hidden therein. Ashcroft, Griffiths and Tiffin (2007) have indicated, of contrapuntality, that:

By thus stressing the affiliations of the text, its origin in social and cultural reality rather than its filiative connections with English literature and canonical criteria, the critic can uncover cultural and political implications that may seem only ớleetingly addressed in the text itselfô

Contrapuntal significations, therefore, refer to notions hidden in the text which reveal the innumerable possibilities of meaning around the óperipheralityô of silences and subtextual connotations in the unfolding of events of such a text. Signification attests ñto a whole tissue of signifiers, potentially endless, through which meaning moves and slips in an elusive play of significationò 
(Reinelt and Roach, 1999). It, therefore, attests to deconstructive reading.

Clash of cultures does not serve as the meaning of the text but only as a mark or hint at possible meaning; as leitmotif, hence, the attempt to give it centrality in this studyôs interpretation. This is against the pervasive tendency of seeing the play as anything but about clash of cultures. Pilkings, for instance, is seen as ó mere catalytic incidentô Elesin is either seen as unwilling or as a victim of the óbjectificationôof women. Olunde is normally perceived as a lover of his culture who gave his life to restore balance to his race and dignity to his family line. By challenging these ćanonical criteriaQ̂ this study engages contrapuntality in drawing out significations that indicate the play as about clash of cultures while further pointing towards other possible interpretations.

The play text presents us with a world laid on the foundations of myth, roles (honour) and responsibilities (duty) communally shared and, thus, upheld. As such, some scholars have stayed within the periphery of this world which on its own terms never triggered a tragic concern in the play. Elesin never refused outright to commit suicide, he was stopped; Olunde was never required to commit suicide, he chose to. But such is the world the play presents: a world rife with meaning in search of interpretations. Within the matrix of that world, are contestations deriving largely from the presence and interference of an alien world which spark up discontinuity and tamper with the orderliness of its hostôs existent cosmos. The opening scene of the play reveals a people who are purposeful and festive in their endeavours. The stage directions reveal that:

Elesin Oba enters along a passage before the market, pursued by his drummers and praise-singers. He is a man of enormous vitality, speaks, dances and sings with that infectious enjoyment of life which accompanies all his actions (Soyinka, 2012).

There is a buoyant celebration which projects an atmosphere of joy and contentment often alluded to the African way of life. This explains why the market is the setting. It is a trade place for cultural pride and aesthetics. The people are seen to be 
carrying out their tasks with relish and delight. Yet there is a hanging premonition of doom in such a festive ambience. The stage directions have earlier portended thus: a passage through a market in its closing stages. The stalls are being emptied, mats folded. A few women pass through on their way home, loaded with baskets. On a cloth-stand, bolts of cloths are taken down; display pieces folded and piled on a tray (Soyinka, 2012).

This is a sign of the arrival of twilight, not only for the market which is a symbolic microcosm of the world for the Yoruba, but of a civilization, of a culture, of a people; aye l'oja orun ni'le. The women who pass through the market on their way home, loaded with baskets connote that once the market (world) is over, each would go home (orun) with oneôs loaded baskets (deeds). Elesinôs market is about to close. An end approaches, which for the purposes of this study is not blamed on Elesinôs procrastinatory exhibitions but on Pilkingsô intervention in stopping the course of the ritual suicide by arresting the subject. The wedding only lasts for a moment, after which, but for the arrest, Elesin proceeded with the ritual.

By honing the tone of hope and failure (despair), of gloom and doom, of life and death (binaries) in the marketplace, the text draws significant value when it makes the marketplace the battleground for the contestations of actions and cultural wills. Quayson (2001) acknowledges:

That this stage of the action is at the marketplace in the twilight of evening adds even further suggestiveness to the unfolding events, for Yoruba culture holds the marketplace itself to be a special location. Its significance lies even deeper in an inclusive idea of sacred space which also extends to orita (crossroads), the favoured locale for ritual sacrifice; it is a luminal arena where the spirit world and the real world meet. A proverb in the language affirms that áhe world is a market and 
heaven is homeôshowing how important the

marketplace is in the cultureôs conception of cosmos.

By striking the natural flow of life of the Yoruba at the marketplace, Pilkings attacks the very essence of a people and the entirety of their cultural universe. Pilkingsô interference with everything has led to catastrophic repercussions. There is an underlying attack on the colonial affair upon African subjects who serve under it directly. Amusa, for instance, noted as a good and reliable police officer (Soyinka, 2012), even though a óMoslem,ô has deep respect for his native tradition, at least the regalia that represent them. Joseph, on the other hand, who is the houseboy of the Pilkingses has been totally eroded of his tradition by Christianity, the white manôs religion:

Pilkings (wearily): Oh, come in Joseph! I donâ know where you pick up all these elephantine notions of tact. Come over here.

Joseph: Sir?

Pilkings: Joseph, are you a Christian or not?

Joseph: Yessir.

Pilkings: Does seeing me in this outfit bother you?

Joseph: No sir, it has no power.

Pilkings: Thank God for some sanity at last. Now

Joseph, answer me on the honour of a Christiané

(Soyinka, 2012).

The implication here is that Christianity which came via colonialism makes one more subservient and devoid of native identity. Pilkings is even amazed at Joseph for trying to be more English than the English. Joseph appears as a robot while Amusa, whose name could actually stand for the corruption of the English word ámuserô with all the amusing (pun intended) embarrassments he suffered in the hands of the women in the 
market, still cuts the figure of a man doing his duty; but not without the emasculating blight his connection to Pilkings invokes:

Amusa: I am tell you women for last time to commot my road. I am here on official business.

Woman: Official business you white manôs eunuch?

Official business is taking place where you want to go and itôs a business you wouldnâ understand.

Woman (makes a quick tug at the constableôs baton): That doesnâ fool anyone you know. Itôs the one you carry under your government knickers that counts. (She bends low as if to peep under the baggy shorts. The embarrassed constable quickly puts his knees together. The women roar.) é .

Woman: Go back and tell the white man who sent you to come himself.

Amusa: If I go I will come back with reinforcement.

And we will all return carrying weapons.

Woman: Oh, now I understand. Before they can put on those knickers the white man first cuts off their weapons.

Woman: What a cheek! You mean you come here to show power to women and you donâ even have a weapon (Soyinka, 2012).

Although highly humorous, this scene reveals the deep disaffection seated in the hearts of the natives for Pilkings, what he represents and all that represent him. This is especially so because, Pilkings contrasts their worldview and belief system. When he is told by his wife, Jane, that óbastardôis not a word to be traded at will in áhese partsôbecause the natives find it quite insulting, he rubbishes her off calling her a ñsocial anthropologistò while 
attacking the extended family practice of the natives (Soyinka, 2012). The cancerous effect of Pilkingsô interference with the nativesô way of life takes an even deeper root when set in oppositional contexts. We see a reversal of binary oppositions; modernity versus tradition, while privileging the former would reveal such repercussions.

Within the culture of the Yoruba, in the text, is the concept of betrothal. A parent might pick a spouse for her child if she wishes. Iyaloja has picked a girl for her son and has made necessary arrangements towards a wedding. The commonplace knowledge that the girl is betrothed to Iyalojaôs son hints at a silence which infers that the son has no say in the matter. As the mother wills, so the son must do. Iyaloja has insisted, ñMy sonôs wish is mineò (Soyinka, 2012). This is the native order of things, same as the expected ritual suicide of Elesin Oba. Olunde, who is expected to take over as Elesin, when his father passes on, is made to distort that arrangement when Pilkings decided to ship him to England for studies. This act made Elesin bitter but Pilkings never cared. It is this very act that leads Elesin into seeking a bride at the peak of his journey to ritual suicide. His first son had been taken away by the white man, naturally he needs an heir. Even when the son returns to bury his father, he is still bent on returning to complete his studies rather than staying back to become the new Elesin. Such is the debilitating effect of Pilkingôs interference in the cosmos and psyche of the natives.

Beyond Pilkingsôacts, the textố body language hints at a privileging of African culture over the European opposite. The musical vivacity which introduces us to the Yoruba characters and setting at the beginning of the play sharply contrasts the sounds that welcome the r̃Europeanò scenes. Ebron (2002) had noted that, ñAfrican music is said to create a communal experience.ò Music, therefore, is deployed in this text, on the one hand, to depict the communal and festive nature of the natives. There is, on the other hand, a marked drabness in the musical cues of the European scenes. ñA tango is playing from an old hand-cranked gramophoneò(Soyinka 2012), ñA masqueé The band plays đ́Rule Brittaniaôbadlyé . The orchestraôs waltz rendition is not of the 
highest musical standardò (Soyinka, 2012). This is a deliberate effort to discountenance the Europeans and deny them of their musicality. Tango, waltz and masque are European in demeanour, yet they are not articulately performed in the text. This is further evidence that the text is mainly concerned with the portrayal of culture from the context of difference, of clashes. It counterpoints the basic notion that ñAfican music was generally thought of as noise in the Westò (Ebron, 2002). Pilkings actually says to his wife, on the persistent drumming of the natives that, ñthey (the natives) always find an excuse for making a noiseé ò (Soyinka, 2012). The text presents a disharmonious rendering of discordant tunes which clearly depict European music as cacophonous thus leading to a reversal of notions, a privileging of African music, a deconstruction.

\section{Alterity and the "Othering" of Difference}

The portrayal of difference further implicates the notion of othering, or the other, a postcolonial term for the depiction of cultures in terms of European superiority over the ótherô Africans and Asians, with the latter group attempting to reverse such canonical ordering in a ñpolitics of survivalò (During, 2001). As this article is not consciously interested in postcolonial discourse, difference is not analysed in the frame of otherness but in Mikhail Bakhtinôs more amenable content analysis concept of alterity. Ashcroft et al (2007) indicate that:

The term álterityô shifts the focus of analysis away from these philosophic concerns with otherness $\ddot{i}$ the ápistemic otherô the other that is only important to the extent to which it can be known $\ddot{i}$ to the more concrete ómoral otherôï the other who is actually located in a political, cultural, linguistic or religious contexté .

Culture is, hence, not apprehended from óthernessô but from its apartness, from its distinctiveness: The novelist must understand his or her character from within, as it were, but must also perceive it as other, as apart from its creator in its distinct 
alterity. Importantly, dialogue is only possible with an ótherô so alterity, in Bakhtinôs formulation, is not simply áxclusionô but an apartness that stands as a precondition of dialogue, where dialogue implies a transference across and between differences of culture, gender, class and other social categories (Aschroft et al, 2007).

It is on this ground that cultural values embedded in the text are analysed in their pretextual rights. Playwrights who create texts that have intercultural encounter, as Death and the King's Horseman does, are often obliged in alterity to understand the cultural parlance of characters they create in context ápartôfrom the creatorôs person and intentions. The charactersô cultural distinctiveness becomes a precondition for dialogue so as to express the alterity of conflicting values. This provides a platform for a contrapuntal interrogation of cultural values by projecting African (Yoruba) values side by side European perceptions of modernity. This is important because, as Quayson (2001) notes, ñthe events in the play areé placed within the context of colonial realities in which Yoruba culture is under the domination of a clumsy British administration.ò Aschroft et al (2007) state that, ñthe self-identity of the colonizing subject, indeed the identity of imperial culture, is inextricable from the alterity of colonized others, an alterity determined, according to Spivak, by a process of othering.ò

Alterity that presents a potential of clash of cultures taps from contrapuntal potentialities of viewing dialogue between racial and cultural óthersôas an important platform for engaging aspects of Death and the King's Horsemanôs pretext, text and context. Contrapuntality as an argument in this article, helps us to see cultures in the light of ñ dialectic category to be apprehended as a field of contending forces: a milieu of exchange, encounter, confrontation and possibly conflictò (Bel, Brouwer, Das, Parthasarathi, Poitevin, 2010).

Cultural values are, generally, commonly held beliefs and standards of what is right or wrong, acceptable or unacceptable, permissible or impermissible, relevant or irrelevant, workable or unworkable within the unique ápartnessôof specific communities (cultures). Hence, by drawing two different cultures into a 
common text, a common ground for interaction, there is certainly bound to be exchanges that instigate conflict via either the intolerability of difference or the imposition of oneôs uniqueness upon an ótherô or both. This apparently provides nexuses for clash of cultures. Such a tendency, of having two distinct cultures in the same text, is a bountifully fertile ground which nourishes the seeds of conflict planted in Death and the King's Horseman and harvested in its production as performance text.

A fundamental base and primacy in the cultural ordering of social life is community. Life is organized around the essence of communities. This is why culture is often defined from community angles; of collectives, groups, a q́eopleôsô way of life, not individual idiosyncrasies. The Africans are aware of this. That is why all roles and actions are intricately connected to yield benefits for the community. But so do the Europeans; Pilkings is in the midst of the natives for king and country. Left to his personal whims and caprices, he bets that he would have been ñsleeping peacefully at homeò (Soyinka, 2012); home, being England, of course. So, respect for community is an essential cultural value. The value of the African lies, in the text under study, in the act of a man to commit suicide in order for the community to survive. It is an accepted norm, at least among the natives. The Europeans also accept that a man can give up his life in order to save others from harm, but that has to be circumstantially necessary, especially when there are no visible options at sight. These notions appear subliminally appropriate in their apartness until a dialogue occurs between them. The European value system discredits the wilful act of taking oneôs life as criminal while the Africans consider it necessary for existence and is a primordial form of renewing life and society. The textual analogy of the Captain who blows himself up to save the harbour to Elesinôs task of committing wilful suicide to save his race did not stop the conflict that emanates from a clash of cultures (Soyinka, 2012).

One of the most vocal characters in Death and the King's Horseman is Jane Pilkings. The immediate relevance of her characterization and status in the text is no other than the fact that she is the wife of the District Officer, Simon Pilkings. Yet she 
engages in cultural debates and is quite loquacious wherever and whenever she gets the chance to freely express herself. This trait could suggest that European wives are free to express themselves as they deem fit. In contemporary society, most women clamour for such a free-spirit; such óightôand freedom. That, for them is modernity. The only other character highlighted, though in contradistinction, áinderôthe spotlight of her husband, as a wife, is The Bride. Swapped from her betrothed role to one man to the wife of another in a matter of minutes, the nameless African character does not utter a single word from the beginning of the dramatic text to the end. This would connote that African wives are indeed subservient, hence, having no place in that ómodernnessô which carries a European ácivilisedô appeal, especially to the contemporary woman. Jane could order her husband to command his subjects into obedience (Soyinka, 2012) but the Bride remains muted to subjection, voiceless. Yet she is the one, in her seemingly murky meekness, who carries the fading and precarious but all important hope of the race.

The spine of the cultural values that lies with the Yoruba community is perhaps the notion of destiny. Communal roles and responsibilities are tied to the belief in predetermination. An Elesinôs blood, for instance, already defines for him the responsibility to commit ritual suicide whenever a King dies, and once he is dead his first son is required to become Elesin after him, thus maintaining both cosmic and terrestrial balance. This is hardly reversible and the community accepts it as an important value system; destiny is sacrosanct and none can escape it. In fact, the ability of an Elesin to go ahead with the suicide provides a space of endearment and reverence among the members of the community for him. Failure to achieve this can be as degrading as being referred to as ñan eater of left-overò, a man of no consequence. This is the cultural normalcy of the Yoruba in Death and the King's Horseman.

For the Europeans, destiny is not a foreclosure of what one must be in life. For them, destiny is a result of manôs independent choices and actions; hence, no one should be mandated by any native custom to take any action detrimental to oneôs own freewill and life. 
It is this belief system that leads Pilkings into abducting Olunde and sending him to England for studies, even at the expense of the Yoruba belief system that the first son of the Elesin must replace his father when the father is dead. It is also that European worldview that could not comprehend the eager expectation of an entire community on an individual to die willingly on their behalf. For PilkingsôEnglish mindset, that is at best barbaric and must be stamped out. That is the nature of his colonial mandate. On the ritual suicide, this conversation ensues between him and his wife after reading Amusaôs report on the impending action of the ritual suicide:

Jane: Did I hear you say commit death?

Pilkings: Obviously he means murder.

Jane: You mean a ritual murder?

Plikings: Must be. You think youôe stamped it all out but itố always lurking under the surface somewhere (Soyinka, 2012).

In order to establish the óupremacyôof his belief system he breaks the flow of the process of ritual suicide thus unleashing a string of clashes emanating from a difference in cultural perceptions and values. With all the intensity of tensions generated by the clash of cultures, the text presents an inadequate dialogue between two cultural frontiers which seem both insoluble and nonadaptive. Both cultures are rigidly preconditioned, conceptually insulated and axiomatically fixated beyond negotiations for acculturation and enculturation to mutual influences and potential interactive benefits. This strain leads the conflict of cultures in Death and the King's Horseman into deeper consequences. In this regard, Quayson (2001) claims that:

Like the babalawo, he (Soyinka) engages with the myths of the gods (culture) to extract contemporary significance, but, unlike them, his prescription for coping with the stress of cultural transition is not propitiatory rites but an assertion of will to 
the utmosté . The notion of the frontier is significant for Soyinka as he meditates on the relationships between his cultureôs conceptual system and its place in the world (emphasis mine).

Cultures in contemporary life are open to influences. One of its keys is its fluidity, its ability to evolve rather than being a static cosmic viscosity. Although the stubbornness of cultural wills between the two cultures propels the tragic consequences of the text in uncompromising proportions, the world today requires diplomacy and integration even as identity remains central in both the uniqueness and differences of cultures, both local and global.

\section{Conclusion}

The meaning of a text is neither dependent on the author nor proclamations of those who support, and celebrate his or her notions. A text can mean anything, depending on itself, any given context or the reader. By applying deconstruction, this article has revealed that Death and the King's Horseman can be about álash of culturesôwithout reducing its essence as a text and as a sample for the ǵgenreficationô and definition of African tragedy. Indeed, various significations abound in the text which demonstrates contrapuntal implications of placing two different cultures within the universe of the same text. This difference in worldviews is bound to instigate clashes inadvertently since conflict is the hinge upon which the dramatic oak swings. Death and the King's Horseman presents such a universe and thrives on the leitmotif of cultural difference and their clashes. 


\section{References}

Adeniran, T. (1994). The politics of Wole Soyinka. Ibadan: Fountain Publications.

Aristotle. (1971). Poetics. In Hazard Adams (ed.). Critical theory since Plato (pp. 48-66). New York: HarcourtBrace Jovanovich Inc.

Ashcroft, B., G. Griffiths and H. Tiffin (2007). Post-colonial studies: Key concepts. London: Routledge-Taylor and Francis.

Aston, E. and G. Savona (1999). Theatre as sign-system: A semiotics of text and performance. London: Routledge.

Balme, C.B. (2008). Introduction to theatre studies. Cambridge: Cambridge University Press.

Barry, P. (2002). Beginning theory: An introduction to literary and cultural theory. Manchester: Manchester University Press.

Beier, U. (Trans.) (1964). Duro Ladipo: Three Yoruba plays; Oba Koso, Oba Moro, Oba Waja. Ibadan: Mbari Publications.

Bel, B., J. Brouwer, B. Das, V. Parthasarathi and G. Poitevin (eds.). (2010). Communication, culture and confrontation. Los Angeles: Sage Publications.

Cuddon, J. A. (1999). Dictionary of literary terms and literary theory. London: Penguin Books.

Derrida, J. (1984). Margins of philosophy. Trans. A. Bass. Chicago: Chicago University Press.

Dobie, A. B. (ed) (2012). Theory into Practice: An Introduction to Literary Criticism. Boston: Wadsworth Cengage Learning.

During, S. (ed) (2001). The cultural studies reader. London: Routledge and Taylor and Francis.

Ebron, P. A. (2002). Performing Africa. New Jersey: Princeton University Press.

George, O. (1999). Cultural criticism in Wole Soyinkâ̂ Death and the King's Horsemanò. Representations, 67, 67-91

Gibbs, J. (ed). (1980). Critical perspectives on Wole Soyinka. Washington: Three Continents Press Inc. 
Idegu, E. U. (2007). ñBeyond the Yoruba cosmology: A contestation of the Africanness of

Wole Soyinkaôs submission in Myth, Literature and the African Worldò. African Performance Review, 1 (2/3), 99-113.

Jeyifo, B. (1985). The truthful lie: Essays in sociology of African drama. London: New Beacon Books Ltd.

Katrak, K. H. (1986). Wole Soyinka and modern tragedy: A study of dramatic theory and practice. New York: Greenwood Press.

Obafemi, O. (1996). Contemporary Nigerian theatre: Cultural heritage and social vision. Bayreuth: Bayreuth African Studies.

Quayson, A. (2001). The space of transformations: Theory, myth, and ritual in the work of

Wole Soyinka. In Biodun Jeyifo (ed.), Perspectives on Wole Soyinka: Freedom and complexity (pp. 201-236). Mississippi: University Press of Mississippi.

Reinelt, J. G. and J. R. Roach (eds.). (1999). Critical theory and performance. Michigan: The University of Michigan Press.

Said, E. (1993). Culture and imperialism. London: Chatto and Windus.

Soyinka, W. (2012). Death and the King's Horseman. Ibadan: Spectrum Books Ltd.

Yerima, A. (2009). Discourse on tragedy. Minna: Gurara Publishing. 